\title{
Plate convergence west of Patagonia and the Antarctic Peninsula since $61 \mathrm{Ma}$
}

\author{
Graeme Eagles $^{\mathrm{a}, *}$, Benjamin G.C. Scott ${ }^{\mathrm{b}, 1}$ \\ alfred Wegener Institute, Helmholtz Centre for Polar and Marine Research, Am Alten Hafen 26, Bremerhaven D-27568, Germany \\ b Department of Earth Sciences, Royal Holloway University of London, Egham, Surrey TW20 OEX, United Kingdom
}

\section{A R T I C L E I N F O}

\section{Article history:}

Received 3 September 2013

Received in revised form 23 April 2014

Accepted 1 August 2014

Available online 10 August 2014

\section{Keywords:}

Antarctica

Pacific Ocean

Fracture zones

Plate motion

Seafloor spreading

Subduction

\begin{abstract}
A B S T R A C T
A new plate kinematic model portrays plate motions immediately west and south of Drake Passage in the southeast Pacific Ocean. Overall intermediate-to-slow rate spreading generated oceanic lithosphere as the Phoenix plate diverged from the Antarctic plate. The model shows a history of Phoenix plate motion that is interpretable as having been affected by a northeast-increasing gradient in the slab pull force since chron 18 (39 Ma), during which time newer, less dense lithosphere was subducting in the southwest than in the northeast. The model allows first calculations of Phoenix-Farallon (Nazca) plate motion parameters in the south Pacific plate circuit. Using these parameters, it is possible to show that the simplest assumptions about the ridge's segmentation, length and migration are consistent with existing suggestions of its location from consideration of slab window-related volcanism at sites in South America around 50 and $20 \mathrm{Ma}$. The parameters thus define ridge locations that can be used to define which plates were subducting beneath South America and the Magallanes and Antarctic plates, and when. We consider the relationships between the plate convergence rate, obliquity and the history of magmatism on the Antarctic Peninsula and at the North Patagonian batholith, showing that magmatic pulses can be related to accelerations in the plate convergence rate. Between these settings, Phoenix-South American plate motion was almost parallel to the Fuegian trench. Here, magmatism in Paleocene to early Miocene times must be related to the presence of a slab subducted beneath the region by the less oblique collision further north. Later magmatism can be related to migration of the Phoenix-Farallon ridge and Phoenix-FarallonAntarctic triple junction into the area south of the Fuegian margin, which brought it into slow low-obliquity convergence with first Farallon and then Antarctic plate lithosphere.
\end{abstract}

(c) 2014 Elsevier B.V. All rights reserved.

\section{Introduction}

Cenozoic plate motions in the southeastern Pacific Ocean are not completely known, owing to the fact that much of the seafloor they created has subducted beneath the region's eastern margins with continental South America and Antarctic Peninsula. As the oceanic plates that made up this seafloor subducted, parts of mid-ocean ridges between them were subducted too, steering the spread and evolution of ventspecific fauna between the Pacific and Atlantic oceans (Roterman et al., 2013), and permitting intraplate volcanism by decompression melting of juvenile mantle beneath the resulting slab windows (Hole and Larter, 1993; Espinoza et al., 2005). The rate and angle of subduction also influenced tectonic and magmatic processes in continental Patagonia and Tierra del Fuego that were important for the paleogeography, paleoenvironment and paleobiogeography of the fragmenting Patagonian-Antarctic land bridge and evolving Drake Passage oceanic gateway.

\footnotetext{
* Corresponding author.

${ }^{1}$ Now at: Department of Natural Sciences, University of Bath, Claverton Down, Bath, BA2 7AY, United Kingdom
}

Fig. 2 portrays the region in mid Miocene times, since which time its evolution is relatively well known. South of Tierra del Fuego, Drake Passage was widening by the separation of two small plates, the western of which (the Magallanes Plate) was moving only slowly with respect to South America (Eagles et al., 2005). To the west, the southernmost segment of the Chile Rise (the Nazca-Antarctic divergent plate boundary) was beginning to collide with the South American margin (Cande and Leslie (1986). The southern end of this segment connected to the Phoenix-Antarctic and Phoenix-Nazca ridges at a triple junction. After subduction of the triple junction, the plate boundary at the South American margin became segmented into three separate lengths. The northern length saw subduction of the Nazca plate below the South American plate, accompanied by volcanism in the Southern Volcanic Zone (Stern, 2004). The central length accommodated slow convergence between the Antarctic Plate and the South American and Magallanes plates, which was very oblique to the margin south of Tierra del Fuego. Relative motion at the southern length was with respect to the Phoenix Plate, and almost parallel to the Fuegian margin. The Phoenix Plate was incorporated into the Antarctic plate at $3.3 \mathrm{Ma}$ (Larter and Barker, 1991; Livermore et al., 2004; Eagles et al., 2005), since which time the entire Fuegian margin has accommodated oblique 


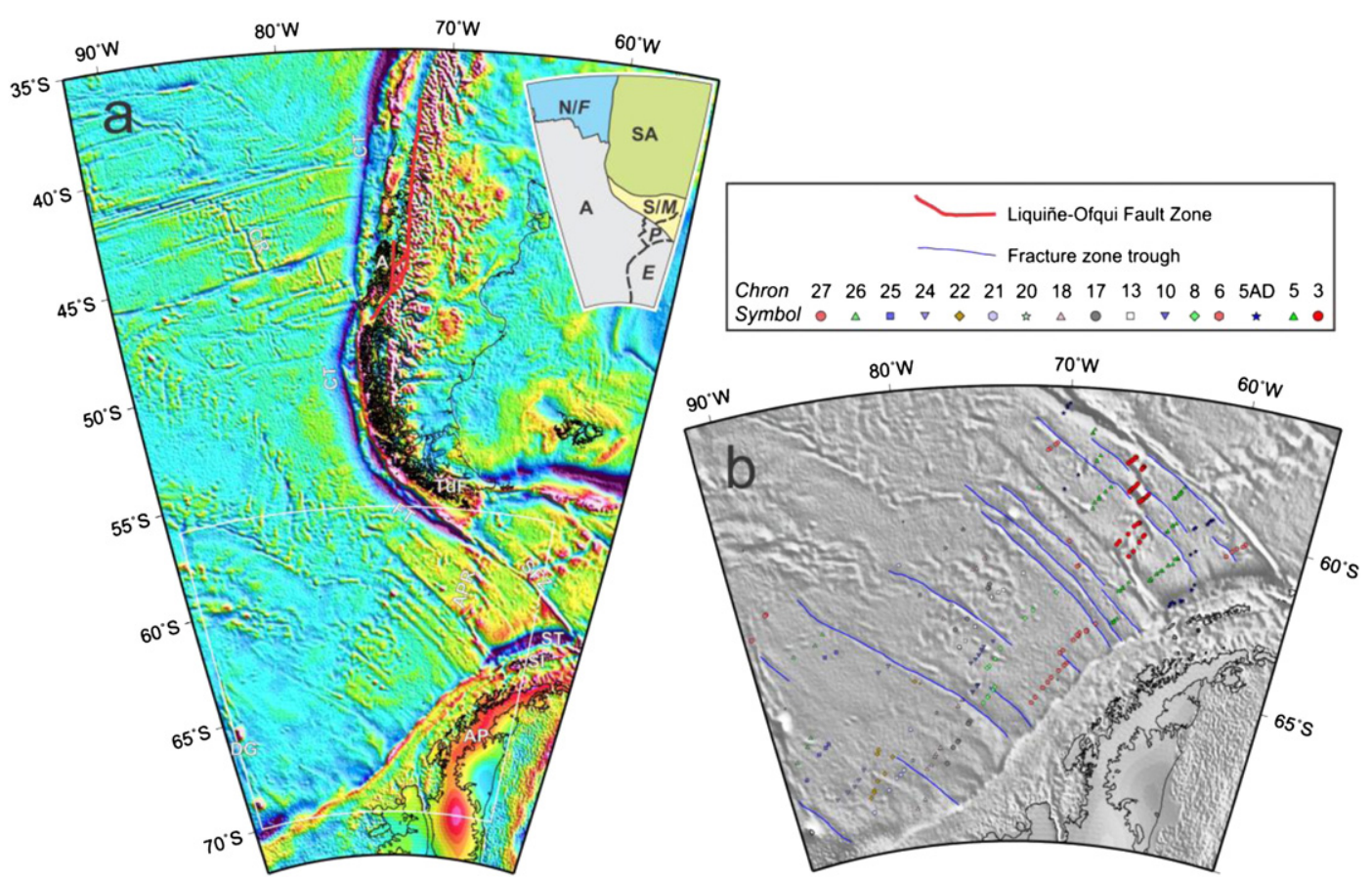

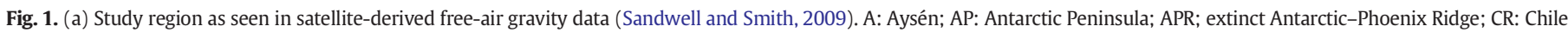

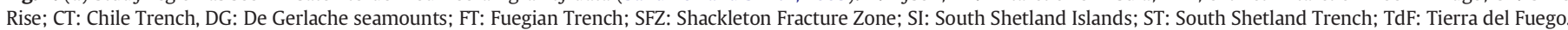

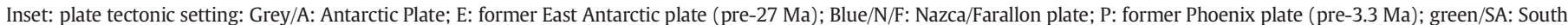

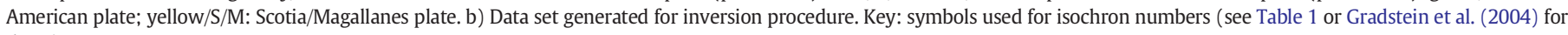
dates).

convergence (Smalley et al., 2007). Post-mid-Miocene subductionrelated volcanism in this so-called Austral Volcanic Zone is all of recent age (Hervé et al., 1984; Puig et al., 1984; Stern, 2004).

Prior to mid-Miocene times, less is known in detail about the nature of the South American margin. Calculations show that some of the margin would have accommodated plate convergence by subduction of the Nazca plate and its predecessor, the Farallon plate. Pardo-Casas and Molnar (1987) calculated the rate of this subduction and noted that it correlates with phases of Andean orogenesis in Peru. Towards the south, it is suggested on the basis of indirect evidence that the Farallon plate's boundary with the Phoenix plate was subducted beneath the South American margin (Cande and Leslie, 1986; Espinoza et al., 2005;
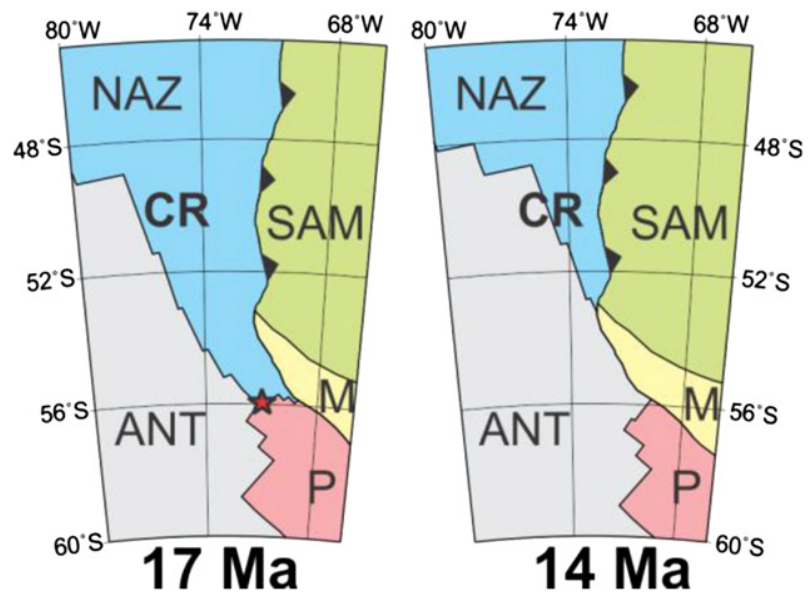

Fig. 2. Miocene evolution of the western margin of the South American plate, after Cande and Leslie (1986) and Eagles et al (2004b). Plate color codes as in Fig. 1, plus pink: Phoenix plate. Red star: Phoenix-Antarctic-Nazca triple junction. ANT: Antarctic plate; CR: Chile Rise; M: Magallanes plate; NAZ: Nazca plate; SAM: South American plate.
Breitsprecher and Thorkelson, 2009; Eagles et al., 2009a; Somoza and Ghidella, 2012). South of this margin, the Phoenix plate would have interacted with the South American margin, but nothing is known about its motion to test these suggestions. Consequently, the reason for the apparent lack of mid-Miocene to Pliocene magmatism in the Austral Volcanic Zone is poorly constrained.

In this study, we contribute to understanding of this region by using an iterative inverse technique to generate new Euler rotations from magnetic anomaly and fracture zone location data. The rotations describe motion of the Phoenix and Antarctic plates in the period 61-3.3 Ma. We apply the rotations in the regional plate circuit in order to depict the location of the subducted Phoenix-Farallon Ridge through time, and to describe the history of plate convergence between the South American and Farallon (Nazca) and Phoenix plates, and the Antarctic and Phoenix plates. We highlight consistencies between the new convergence models and the timing and sources of magmatism along the Antarctic Peninsula and Patagonian Andes.

\section{Antarctic-Phoenix Plate Motion}

The divergent plate boundary between the Phoenix and Antarctic plates was initiated during a regional reorganization of plate boundaries at chron 27 ( $62 \mathrm{Ma}$; Fig. 3; Eagles et al., 2004a,b). The resulting northeast-striking mid-ocean ridge separated seafloor of the West Antarctic plate on its northwestern flank from that of the Phoenix plate on its southeastern flank. The ridge, seen from West Antarctica, thus moved towards the southeast and the Antarctic Peninsula, a part of the East Antarctic plate. As plate motion between the east and west Antarctic plates was slight throughout Cenozoic times (Cande et al., 2000; Cande and Stock, 2004), the net result was subduction of the Phoenix plate beneath the peninsula's northwestern margin. With ongoing subduction in this way, segments of the Phoenix-Antarctic Ridge eventually migrated into collision with the peninsula margin, where they ceased to accommodate any relative plate motion (Barker, 1982; Larter and Barker, 1991). The oldest collisions occurred in the 


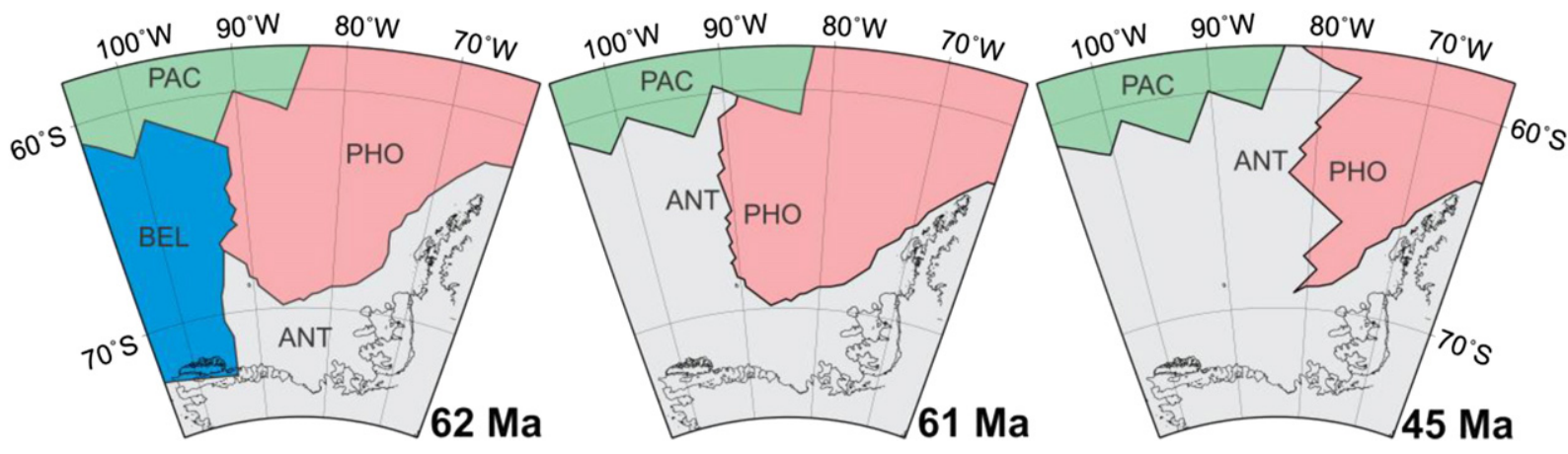

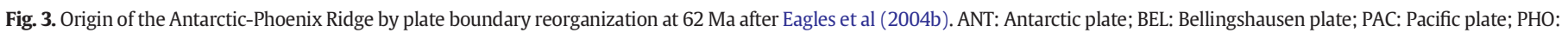
Phoenix plate.

southwest, owing to the mostly left-handed transform fault offsets along the ridge crest that saw its northernmost segments approach from the furthest distances to the peninsula margin. The Phoenix-West Antarctic-East Antarctic triple junction probably followed the northeastwards progress of these collisions, leading to minor extension of the Antarctic Peninsula margin (Eagles et al., 2009b). Spreading ceased at the Antarctic-Phoenix Ridge at 3.3 Ma (Larter and Barker, 1991; Livermore et al., 2000; Eagles, 2004) before the northern parts of the ridge could collide. A small corner of the Phoenix plate thus remained frozen into the interior of the Antarctic plate off the South Shetland Islands.

This small fragment of the Phoenix plate preserves magnetic anomaly isochrons and fracture zones that describe the Phoenix plate's motion with respect to the Antarctic plate in the period after $15 \mathrm{Ma}$ (Eagles, 2004). To the southwest, similar data record the relative motions of the Antarctic-Phoenix Ridge with respect to the West Antarctic plate at earlier times, as a set of stage rotations that can be summed to provide half finite rotations (Nankivell, 1997; Livermore et al., 2005). To a first approximation, this motion can be simply doubled to provide a model of relative motions between the Phoenix and Antarctic plates since $61 \mathrm{Ma}$. In practice, estimates like this are subject to inaccuracy related to asymmetric spreading processes, which have been documented for the system's intact conjugate parts (Eagles, 2004).

\subsection{Magnetic isochrons}

Magnetic anomaly profiles show anomalies that are well-formed owing to the intermediate rate of plate divergence. We re-inspected a set of long profiles sampling the main spreading corridors and found the published magnetic anomaly identifications of Barker (1982), Larter and Barker (1991), McCarron and Larter (1998) and Eagles (2004) to be convincing. We made no large changes to the anomaly identification schemes in those corridors. We plotted all the profiles available to us and picked from them a sequence of thirteen isochrons for modeling (Fig. 1; Table 1). Isochrons for $5 \mathrm{AD}, 5$, and 3 are available from both the Phoenix and Antarctic plates from the northwest of the study area, where not all of the Phoenix plate was subducted.

Pre-5 AD isochrons are only known from the West Antarctic plate. With these data there is no reliable way to recognize system-wide spreading asymmetry, if it occurred, as their conjugates have been completely subducted. Local asymmetries, in individual spreading segments, can be avoided by careful comparison of the spacings of magnetic anomalies in all spreading segments where they appear. Aberrant spacings can be assumed to be the results of episodes of asymmetric spreading, and rotations for these stages can be disqualified from the inversion procedure. This scheme is unworkable for the stage between chrons 13 and 10, which is only represented in one spreading corridor, and forces arbitrary choices in two other instances where the stages $240-220$ and $80-60$ are only represented in two corridors. There is no clear independent indication, such as a fossil ridge segment, in any of these cases to certify which of the corridors experienced spreading asymmetry. In the solution we present, we (i) favored data for the 240-220 stage that imply least spreading rate change during that stage, (ii) used data from both corridors for the 80-6o stage because their differential spacing was moderate, and (iii) used the 13o-10o data from a single corridor with the caveat that unattested asymmetric spreading may have affected the solution for that stage.

\subsection{Fracture zones}

Satellite-derived free-air gravity data (Sandwell and Smith, 2009) show that a set of long northwest-trending troughs, most simply interpretable as fracture zones, is developed in the seafloor formed by the Antarctic-Phoenix Ridge between the De Gerlache seamounts and the Shackleton Fracture Zone (Fig. 1). The fracture zones are not all continuous between the Antarctic Peninsula margin and the trace of the Antarctic-Phoenix-Farallon triple junction that marks the northern edge of this seafloor. The fracture zones are spaced at intervals that vary between $50 \mathrm{~km}$ and $300 \mathrm{~km}$, and they offset magnetic isochrons by distances of $10-150 \mathrm{~km}$. We picked at $10 \mathrm{~km}$ spacing along the troughs of the gravity anomalies to locate the fracture zones for the inversion procedure.

\subsection{Inversion}

The inversion followed a straightforward procedure. We used a set of starting finite rotations based on the results of Eagles (2004) for the younger rotations, and extrapolated them linearly for the older ones. We tested these rotations using the full data set for isochron and fracture zone locations. To do this, the technique calculated a set of

Table 1

Inversion model time steps. Timescale used is Gradstein et al. (2004).

\begin{tabular}{llc}
\hline Isochron label & Timescale label & Timescale age \\
\cline { 2 - 3 } & & $(\mathrm{Ma})$ \\
\hline 3 & C3n.4n old edge & 5.235 \\
5 & C5n.2n old edge & 11.04 \\
$5 \mathrm{AD}$ & C5ADn old edge & 14.58 \\
6 & C6n old edge & 19.72 \\
8 & C8n.2n old edge & 26.15 \\
10 & C10n.2n old edge & 28.72 \\
13 & C13n old edge & 33.74 \\
17 & C17n.1n young edge & 36.61 \\
18 & C18n.2n old edge & 39.46 \\
20 & C20n old edge & 42.77 \\
21 & C21n young edge & 45.35 \\
22 & C22n old edge & 49.43 \\
24 & C24n.3n old edge & 53.81 \\
25 & C25n old edge & 57.18 \\
26 & C26n old edge & 58.74 \\
27 & C27n old edge & 61.98 \\
\hline
\end{tabular}


stage rotations and a set of finite half rotations from the starting set, and used them to generate a set of misfits by rotating magnetic isochrons towards each other and by comparing the FZ picks to synthetic flowlines. Improvements to this set of rotations were calculated on the basis of gradients in the distributions of these misfits, and then applied in the next iteration. A stable solution was found after a few tens of iterations.

\section{Results}

Fig. 4 visually summarizes the model and its fit to the data set. Like the fracture zones, the synthetic flowlines for the most part cross the study area smoothly. The mean and standard deviation of the misfits between the two are 0.0 and $6.8 \mathrm{~km}$. The largest misfits are at the intersections between two chron 6-aged lengths of fracture zone with the inactive subduction zone near $67.0^{\circ} \mathrm{S}$ and $64.5^{\circ} \mathrm{S}$. Here the synthetic flowlines feature a bend at chron 6 that is not seen in the fracture zones. We expect that this bend would appear smoother, and the misfit less extreme, with the use of shorter stages to describe the changes in the system around this time. Alternatively, the misfits might be related to the suggestion that the later stages of ridge crest approach to the trench may have involved fragmentation of the subducting plate and independent motion of the fragments (Larter and Barker, 1991). The magnetic isochron misfits are less tightly distributed, with a mean of $-1.8 \mathrm{~km}$ and standard deviation of $13.3 \mathrm{~km}$. The largest misfits cluster in the northern of the two corridors in which we identified variablyspaced C8-C6 stages.

Fig. 5 and Table 2 summarize the rotations that make up the model. In Fig. 5, the 95\% confidence ellipses surround a set of rotation poles that is situated near to the southwest of the data set. The rotations are about poles that migrate eastwards for chrons 27 to 24 , remain near $110^{\circ} \mathrm{W}$ until chron 18 , and migrate northeastwards again afterwards, following the west Antarctic margin. In his higher-resolution study, Eagles (2004) noted a similar pattern for rotations younger than $15 \mathrm{Ma}$, and suggested that it marked the dominance of a gradient in slab buoyancy forces driving relative motions. As subducting parts of the Phoenix plate would also have been much younger in the southwest than in the northeast since the time of the first ridge-crest-trench collision near chron 18, a similar interpretation can be put forward for the migration of finite poles beginning then.

\section{Locations of ridge subduction beneath Patagonia}

The Chile Rise is a divergent plate boundary between the Antarctic and Nazca plates that evolved out of the divergent Farallon-Antarctic plate boundary as the Farallon plate fragmented into Nazca and Cocos plates at $23 \mathrm{Ma}$ (Meschede and Barckhausen, 2000). The Chile Rise is currently subducting beneath South America, and has probably been doing so since around $17 \mathrm{Ma}$. The collision event is suggested to have been responsible for the opening of a slab window beneath Patagonia, through which fertile mantle that had previously been confined beneath the neighboring slabs welled up. The upwelling is interpretable from occurrences of late Miocene alkali basalt volcanism in Patagonia (Ramos and Kay, 1992; Gorring et al., 1997; D'Orazio et al., 2000; 2001; 2004; Breitsprecher and Thorkelson, 2009), and accompanying phases of uplift and denudation (Fosdick et al., 2013).

Our work describes the first detailed modeling of pre-17 Ma (midMiocene) motions of plates west of Patagonia other than the Antarctic and Nazca plates, which are yet to be subducted. A variety of somewhat speculative reconstructions of plate motions in the region through those times nonetheless exist in the literature. Among these, many simply extrapolate the presence of the Nazca or Farallon plates from the better-known region further north (Brown et al., 2006; Sdrolias and

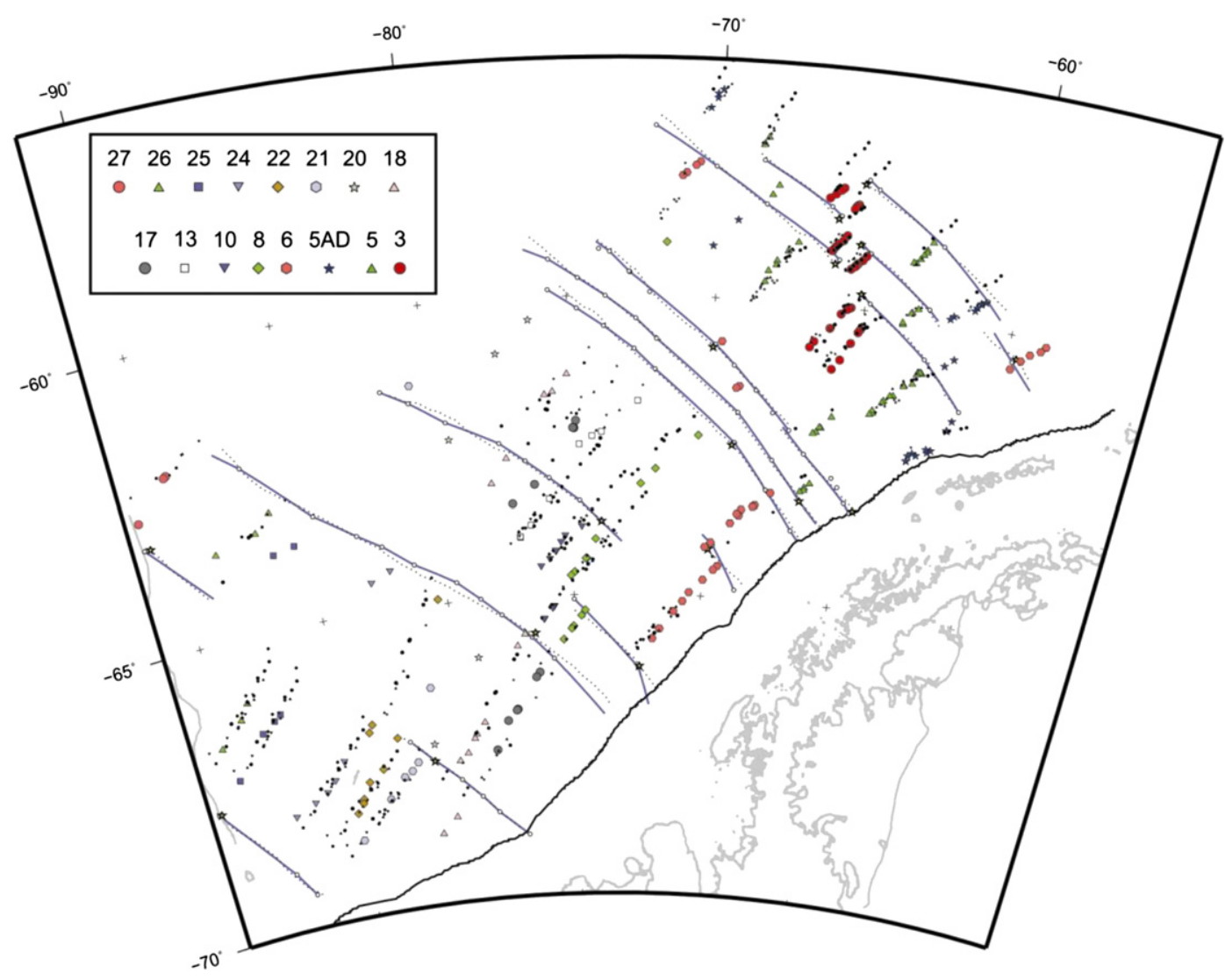

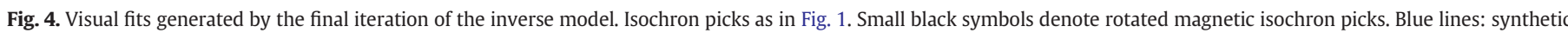
flowlines; small black triangles: FZ picks from gravity data. 


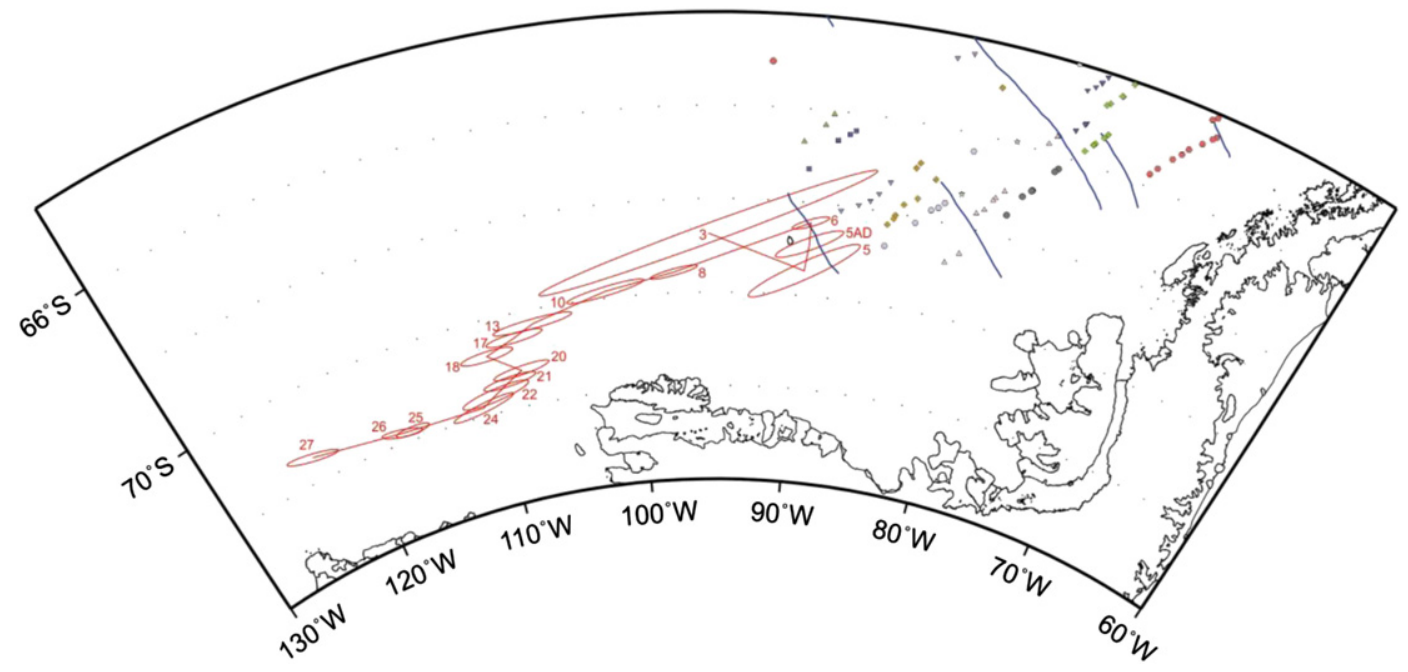

Fig. 5. Two-dimensional 95\% confidence ellipses for the finite rotations, labeled by isochron number. Others symbols as in Fig. 4.

Müller;, 2006; Seton et al., 2012; Maloney et al., 2013). However, there are reliable proximal constraints on the presence of a mid-ocean ridge at the southern edge of that plate in the form of magnetic isochrons that locate triple junctions involving the Antarctic-Phoenix, PacificFarallon/Nazca, and Pacific-Phoenix ridges. Using this constraint, Cande and Leslie (1986) sketched a northeast-oriented PhoenixFarallon/Nazca ridge at the Antarctic-Phoenix-Farallon triple junction in Paleogene and Neogene times, and suggested that its northeastern reaches were simultaneously subducting at the Chile Trench. In Patagonia, Espinoza et al. (2005) and Breitsprecher and Thorkelson (2009) related alkali basalts at $46.75^{\circ} \mathrm{S}$ and dated to 50 Ma with the ${ }^{40} \mathrm{Ar}-{ }^{39} \mathrm{Ar}$ technique to the opening of a slab window by this ridge subduction. Breitsprecher and Thorkelson (2009) and Eagles et al. (2009a) related younger (18.5 Ma) alkali basalt in Tierra del Fuego to a later phase of the same collision. This correlation is more tentative than that of Espinoza et al. (2005) further north, because of the lesser volume of the alkali basalt occurrence and because the dates were determined with the $\mathrm{K}-\mathrm{Ar}$ technique.

Our new rotations enable us to calculate a set of kinematic parameters with which to test these possible constraints on the location of the Phoenix-Farallon/Nazca ridge, by determining relative motion of the Phoenix and Farallon/Nazca plates since $61 \mathrm{Ma}$ in the Phoenix-West

Table 2

Rotations and 95\% confidence regions for reconstruction of the Phoenix plate with respect to the west Antarctic plate since $61 \mathrm{Ma}$.

\begin{tabular}{|c|c|c|c|c|c|c|c|}
\hline \multicolumn{3}{|c|}{ Model rotation parameters } & \multicolumn{5}{|c|}{ 95\% Confidence ellipsoid, $1 \sigma$ great circle degrees } \\
\hline Latitude & Longitude & Angle & Axis 1 & Axis 2 & Axis 3 & Azimuth & Label \\
\hline-68.74 & -95.44 & 1.58 & 1.58 & 0.08 & 0.07 & 19.74 & 3 \\
\hline-69.46 & -89.60 & 12.40 & 0.71 & 0.07 & 0.05 & 29.30 & 5 \\
\hline-68.89 & -89.42 & 21.47 & 0.57 & 0.05 & 0.05 & 24.59 & $5 \mathrm{AD}$ \\
\hline-68.43 & -89.45 & 32.30 & 0.42 & 0.05 & 0.03 & 20.57 & 6 \\
\hline-69.56 & -97.57 & 40.60 & 0.78 & 0.08 & 0.03 & 12.89 & 8 \\
\hline-69.86 & -101.89 & 40.35 & 1.20 & 0.08 & 0.04 & 10.31 & 10 \\
\hline-70.31 & -106.72 & 40.76 & 1.07 & 0.09 & 0.04 & 4.25 & 13 \\
\hline-70.52 & -108.05 & 43.40 & 0.83 & 0.09 & 0.04 & 3.88 & 17 \\
\hline-70.77 & -110.04 & 45.54 & 0.79 & 0.08 & 0.04 & 2.09 & 18 \\
\hline-71.23 & -108.03 & 54.75 & 1.04 & 0.08 & 0.03 & 6.04 & 20 \\
\hline-71.41 & -108.94 & 59.08 & 1.33 & 0.09 & 0.04 & 4.82 & 21 \\
\hline-71.62 & -110.08 & 61.45 & 1.73 & 0.08 & 0.05 & 8.36 & 22 \\
\hline-71.82 & -111.10 & 66.89 & 1.83 & 0.08 & 0.04 & 11.23 & 24 \\
\hline-71.81 & -116.19 & 71.50 & 0.95 & 0.07 & 0.03 & 2.07 & 25 \\
\hline-71.79 & -116.95 & 75.46 & 1.11 & 0.07 & 0.03 & 170.26 & 26 \\
\hline-71.48 & -123.18 & 79.06 & 1.15 & 0.08 & 0.03 & 169.63 & 27 \\
\hline
\end{tabular}

Antarctic-Pacific-Farallon/Nazca plate circuit. Along with the rotations in Table 2, we close the circuit using the Pacific-Antarctic rotations of Cande et al. (1995) and the Farallon/Nazca-Pacific rotations of Rowan and Rowley (2014) and, for comparison, of Pardo-Casas and Molnar (1987). For the motion of the ridge between the Phoenix and Farallon/ Nazca plates, we assume motion at half the rate of the second plate when viewed in the reference frame of the first. The three sets of rotations are generated for different isochrons or different parts of isochrons. Consequently, we complete the circuit using rotations interpolated at 1 Myr intervals. Table 3 lists the interpolated rotations for relative motion of the Phoenix and Farallon/Nazca plates that lie closest to the ages of the isochrons in Table 1.

Fig. 6 shows the region at $50 \mathrm{Ma}$, around the time of the more northerly alkali basalt effusion. The basemap is the gravity data reconstruction of Eagles et al. (2004b), to which we have added data that illustrate the location of the South American plate. We show Phoenix-Farallon plate motion vectors in the reconstruction underlap region that the Phoenix-Farallon ridge may have occupied. The simplest Phoenix-Farallon ridge drawn between the constraining triple junction and the margin at $46.75^{\circ} \mathrm{S}$ would have long segments and a small number of finite-offset transforms. This is consistent with the fast spreading rate predicted by the rotations.

In Fig. 7, the region is shown at $20 \mathrm{Ma}$, as by Eagles et al. (2009a). By this time, the ridge would have separated the Nazca and Phoenix plates, and probably would have consisted of shorter segments and more numerous transforms, owing to its slower spreading rate. Rotating the great circle that the $50 \mathrm{Ma}$ ridge approximates, using the rotations in Table 3, we predict that the Phoenix-Farallon ridge was located off Tierra del Fuego at $20 \mathrm{Ma}$. At its northeastern end, the ridge would have been colliding with the Fuegian margin, consistent with the interpretation of a slab window source for the $18.5 \mathrm{Ma}$ alkali basalt effusion at Packsaddle Island (Puig et al., 1984; Breitsprecher and Thorkelson, 2009; Eagles et al., 2009a). The hypotheses of Eocene and early Miocene alkali basalt volcanism in Patagonia being related to subduction of the Phoenix-Farallon/Nazca ridge beneath South America are therefore self consistent, mutually consistent, and consistent with our model of regional plate kinematics.

\section{Phoenix and Farallon plate motions at the Pacific margins of Antarctica and Patagonia}

Our new Phoenix-Antarctic rotation model enables us to quantify convergence between the oceanic plates of the southeast Pacific and 
Table 3

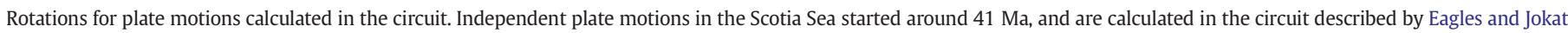
(2014).

\begin{tabular}{|c|c|c|c|c|c|c|c|c|c|c|c|c|}
\hline \multirow{2}{*}{$\frac{\text { Time }}{\mathrm{Ma}}$} & \multicolumn{3}{|c|}{ Phoenix-Farallon/Nazca } & \multicolumn{3}{|c|}{ Phoenix-South America } & \multicolumn{3}{|c|}{ Farallon/Nazca- South America } & \multicolumn{3}{|c|}{ Phoenix-Magallanes/Scotia } \\
\hline & Latitude & Longitude & Angle & Latitude & Longitude & Angle & Latitude & Longitude & Angle & Latitude & Longitude & Angle \\
\hline 5 & -55.44 & 93.96 & 4.34 & -78.75 & -126.42 & 2.90 & -55.44 & 93.96 & 4.34 & -75.27 & -142.16 & 2.66 \\
\hline 11 & -52.10 & 94.17 & 9.82 & -73.87 & -99.69 & 15.28 & -52.10 & 94.17 & 9.82 & -73.00 & -105.42 & 14.71 \\
\hline 15 & -55.93 & 88.93 & 14.34 & -72.24 & -97.81 & 26.34 & -55.93 & 88.93 & 14.34 & -71.43 & -101.74 & 25.56 \\
\hline 20 & -58.71 & 86.12 & 20.62 & -71.43 & -98.47 & 37.92 & -58.71 & 86.12 & 20.62 & -70.53 & -101.97 & 36.89 \\
\hline 26 & -62.09 & 85.33 & 26.82 & -71.21 & -108.94 & 46.67 & -62.09 & 85.33 & 26.82 & -69.45 & -117.44 & 44.38 \\
\hline 29 & -65.75 & 78.17 & 28.75 & -71.46 & -113.95 & 47.96 & -65.81 & 78.38 & 28.77 & -69.70 & -120.51 & 46.36 \\
\hline 34 & -68.48 & 63.82 & 32.60 & -71.92 & -118.48 & 51.02 & -69.92 & 65.10 & 32.96 & -70.70 & -121.79 & 50.94 \\
\hline 37 & -69.83 & 54.01 & 35.80 & -72.07 & -119.59 & 55.75 & -73.25 & 48.92 & 36.36 & -71.48 & -119.59 & 56.35 \\
\hline 39 & -70.27 & 47.56 & 37.99 & -72.23 & -120.27 & 58.40 & -74.96 & 35.36 & 38.88 & -71.98 & -118.65 & 59.62 \\
\hline 43 & -69.86 & 39.32 & 44.17 & -72.54 & -116.67 & 70.33 & -74.46 & 15.66 & 44.51 & $\mathrm{n} / \mathrm{a}$ & $\mathrm{n} / \mathrm{a}$ & $\mathrm{n} / \mathrm{a}$ \\
\hline 45 & -70.00 & 36.36 & 47.71 & -72.60 & -116.83 & 74.68 & -74.24 & 8.94 & 46.15 & $\mathrm{n} / \mathrm{a}$ & $\mathrm{n} / \mathrm{a}$ & $\mathrm{n} / \mathrm{a}$ \\
\hline 49 & -70.45 & 27.64 & 49.95 & -72.80 & -117.09 & 78.61 & -73.24 & -2.41 & 49.15 & $\mathrm{n} / \mathrm{a}$ & $\mathrm{n} / \mathrm{a}$ & $\mathrm{n} / \mathrm{a}$ \\
\hline 54 & -70.53 & 13.39 & 50.34 & -72.97 & -117.18 & 85.70 & -71.40 & -13.40 & 53.00 & $\mathrm{n} / \mathrm{a}$ & $\mathrm{n} / \mathrm{a}$ & $\mathrm{n} / \mathrm{a}$ \\
\hline 57 & -69.47 & 4.28 & 50.29 & -73.04 & -120.55 & 90.49 & -69.66 & -17.98 & 54.67 & $\mathrm{n} / \mathrm{a}$ & $\mathrm{n} / \mathrm{a}$ & $\mathrm{n} / \mathrm{a}$ \\
\hline 59 & -68.62 & 0.70 & 51.13 & -72.99 & -121.59 & 95.51 & -68.53 & -20.61 & 55.88 & $\mathrm{n} / \mathrm{a}$ & $\mathrm{n} / \mathrm{a}$ & $\mathrm{n} / \mathrm{a}$ \\
\hline 61 & -67.71 & -2.48 & 52.00 & -72.97 & -124.81 & 98.24 & -67.39 & -22.86 & 57.13 & $\mathrm{n} / \mathrm{a}$ & $\mathrm{n} / \mathrm{a}$ & $\mathrm{n} / \mathrm{a}$ \\
\hline
\end{tabular}

the overriding South American and Antarctic plates with greater confidence than previously. To do this, we extend the model South Pacific plate circuit using West Antarctica-East Antarctica rotations from Cande et al. (2000) and Cande and Stock (2004), East AntarcticaSouth America rotations from Livermore et al. (2005), and rotations for Magallanes-South America motion along the North Scotia Ridge since $42 \mathrm{Ma}$ from Eagles and Jokat (2014). The resulting rotations (Table 3 ) enable us to calculate the direction and speed of convergence between the Farallon/Nazca and South American/Magallanes plates, the Phoenix and South American/Magallanes plates, and the Phoenix and Antarctic plates (Fig. 8). Along with the new reconstructions of the Phoenix-Farallon/Nazca ridge's likely location through time, we can calculate convergence estimates in appropriate margin segments in order to consider the history of subduction at the western margins of South America and Antarctica. We show, in particular, that the PhoenixFarallon ridge most likely moved along the South American margin far more slowly than suggested by Cande and Leslie's (1986) or Somoza and Ghidella's (2012) sketches. Much of the southern part of this margin would, therefore, have been affected by Phoenix-South American convergence in Eocene and Oligocene times.

Oceanic-continental convergence affects the overriding continent by facilitating tectonic and magmatic processes in it. Of these, the products of magmatic processes are usually more accurately dated. This is certainly the case for the Andes south of $47^{\circ} \mathrm{S}$, where many segments of the fold and thrust belt can at best be dated at the resolution of the lengths of Cenozoic epochs (Suárez et al., 2000), compared to the sub-million year accuracy to be expected of current radiometric techniques when applied to dating plutonic and volcanic processes. Similar problems dog studies in the Antarctic Peninsula, where exposure is more limited and access is more difficult. In the following, therefore, we concentrate mostly on comparing our model convergence histories to the magmatic record of margin history.

Magmatism along the Antarctic Peninsula seems to have continued throughout the study period (Rex, 1976). This is consistent with the modeled history of continuous low-obliquity Phoenix-Antarctic convergence at the peninsula margin in the 61-3.3 Ma period (Fig. 9). However, the distribution of samples is uneven and the majority of dates available use the $\mathrm{K}-\mathrm{Ar}$ method that is prone to inaccuracy owing to the possibility of sources of excess argon in samples. There is no obvious relationship between their ages and the southwest-to-northeast pattern of ridge-crest-trench collisions and the cessation of subduction. In more details, Wang et al. (2009) presented ${ }^{40} \mathrm{Ar}-{ }^{39} \mathrm{Ar}$ evidence for a $45-44$ Ma magmatic pulse at the South Shetland islands. They related the pulse to delamination

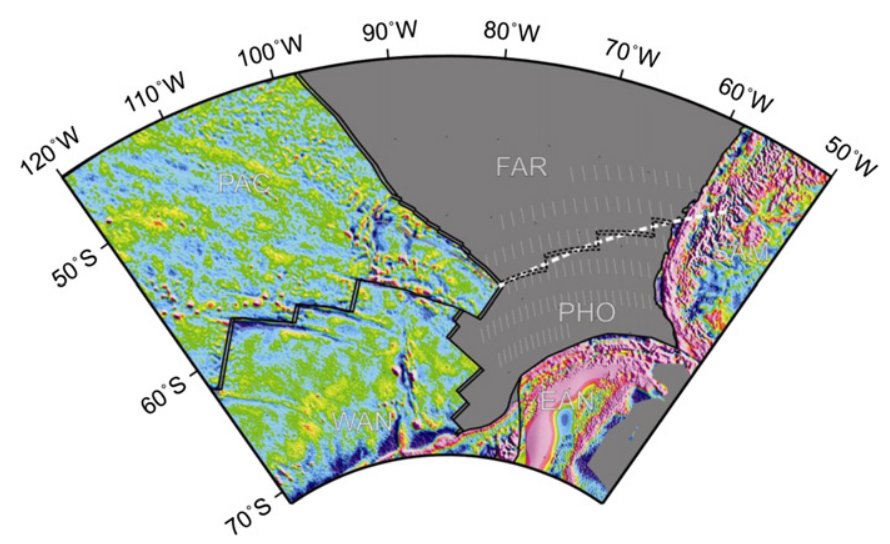

Fig. 6. $50 \mathrm{Ma}$ free-air gravity data reconstruction. EAN: East Antarctic plate; FAR: Farallon plate, PAC: Pacific plate; PHO: Phoenix plate; SAM: South American plate. Thin white lines: Farallon-Phoenix relative plate motion vectors for the period 50-45 Ma. Thick dashed white line: Great circle segment connecting the FAR-PAC-PHO triple junction with outcrops of $50 \mathrm{Ma}$ alkali basalt that have been related to slab window opening beneath Patagonia. A simple fast-spreading ridge morphology is suggested by dashed black lines running along the great circle.

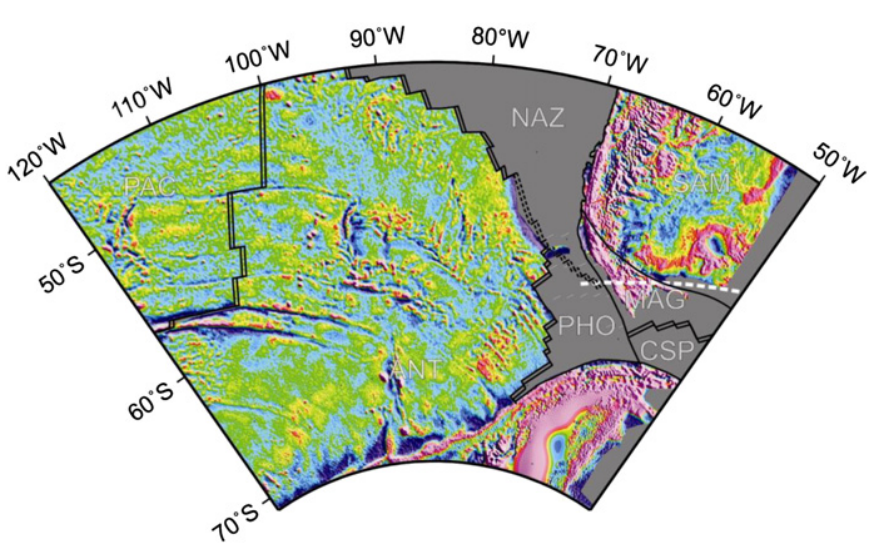

Fig. 7.20 Ma free-air gravity data reconstruction. Labels as in Fig. 6 except CSP: central Scotia Plate; Mag: Magallanes plate; NAZ: Nazca plate. Thin white lines: Farallon-Phoenix relative plate motion vectors for the period 20-15 Ma. Thick dashed white line: great circle segment from Fig. 6 rotated by a 50-20 Ma Farallon-Phoenix stage rotation. A simple slow-spreading ridge morphology is suggested by dashed black lines approximating the great circle. 

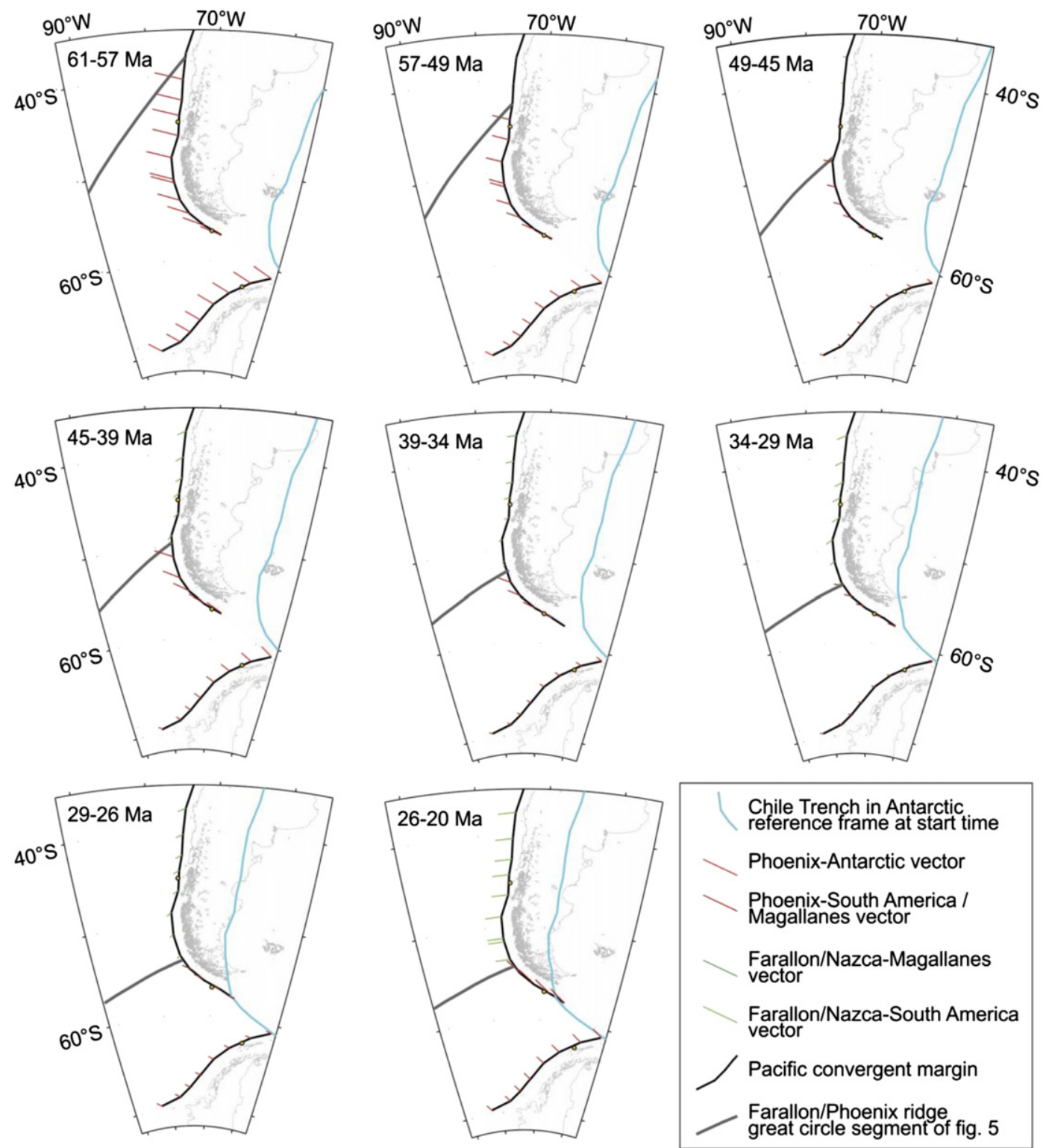

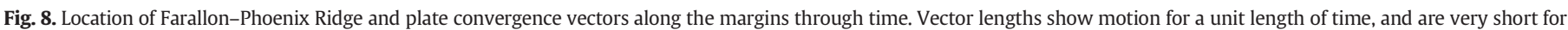
Farallon-South America convergence prior to $49 \mathrm{Ma}$. Circles show the locations used for calculations summarized in Figs. 9-11.

of the overriding plate during what they determined to be a long period of declining convergence rates that started (after McCarron and Larter, 1998) at chron 24 (53.3-52.7 Ma) and continued until $36 \mathrm{Ma}$ (after Barker, 1982).
Our rotations clearly reproduce the onset of this decline, but not its duration until $36 \mathrm{Ma}$. This is because Barker (1982) used an old magnetic polarity reversal timescale with significantly longer polarity intervals after $46 \mathrm{Ma}$ than in either the Gradstein et al. (2004) timescale that we

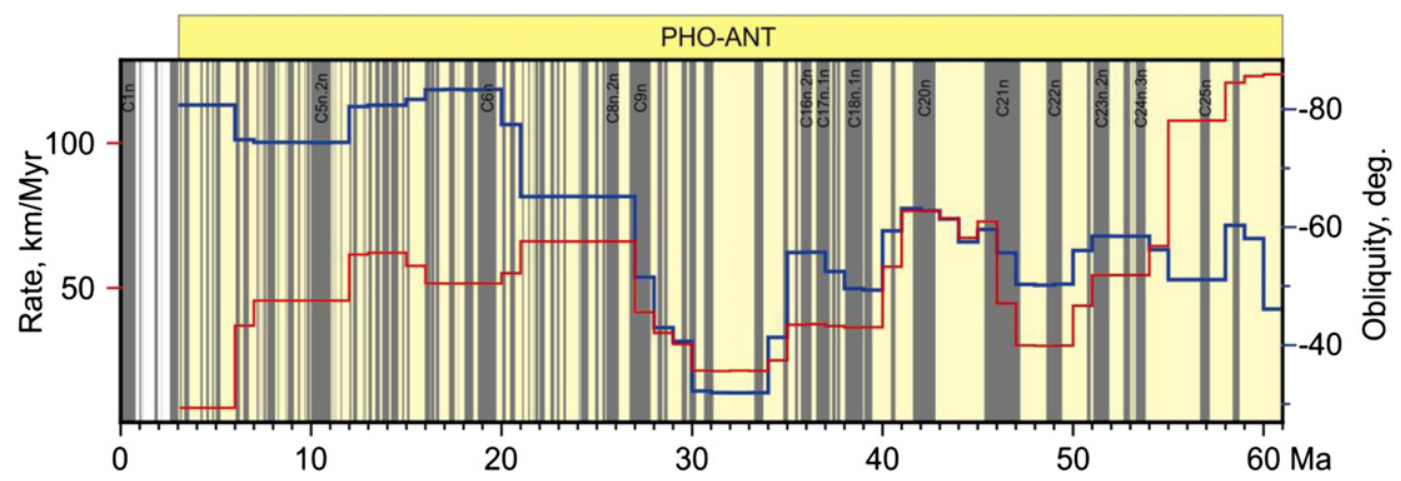

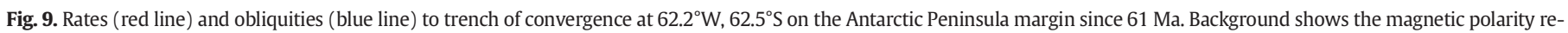
versal timescale of Gradstein et al. (2004). 


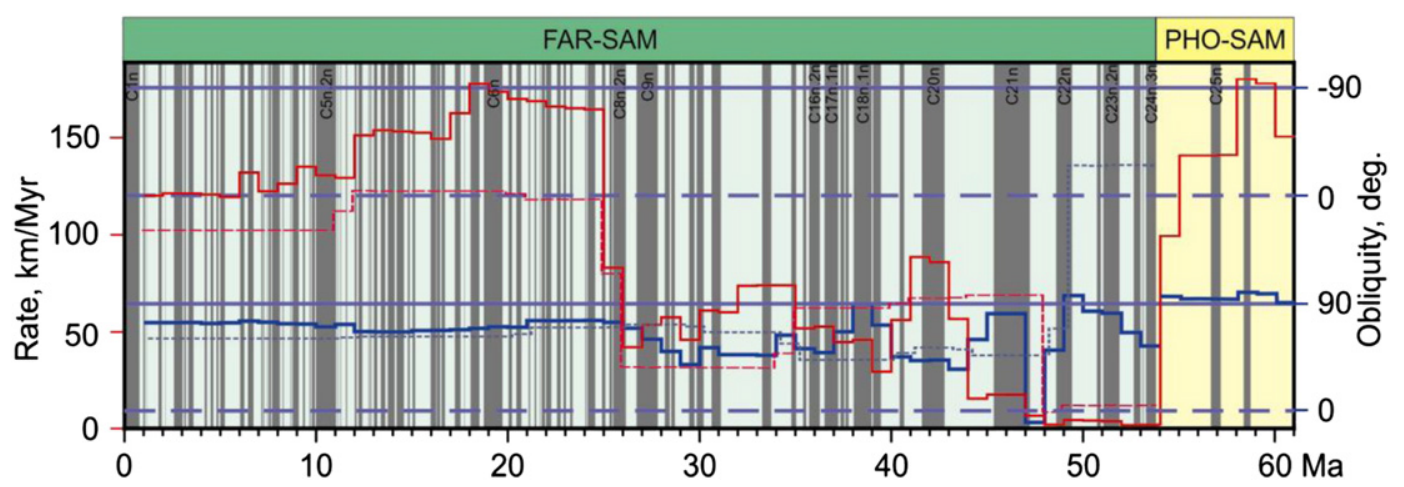

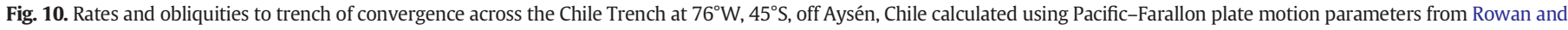

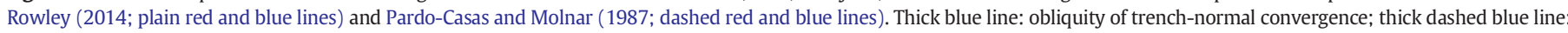
obliquity of trench-parallel motion.

use or the Cande and Kent (1995) timescale used by McCarron and Larter (1988). With either of the newer timescales, our model instead shows the $52 \mathrm{Ma}$ decrease in convergence rates to have lasted until chron 21 (45.3-47.2 Ma in Gradstein et al., 2004). After chron 21, our model's convergence rate increases again by around $40 \mathrm{~km} / \mathrm{Myr}$. The increase is maintained until chron 18 (39.4-38 Ma). Wang et al.'s (2009) magmatic pulse therefore occurs during a period of relatively faster plate convergence. We conclude that the pulse is likely to be simply related to increased melt production in response to faster subduction (Huang and Lundstrom, 2007) brought about by the accelerated convergence.

Further north, Pankhurst et al. (1999) find the North Patagonian Batholith at $44^{\circ}-47^{\circ} \mathrm{S}$ in Aysén, Chile, to be geochronologically zoned, showing evidence for growth during Cretaceous and Cenozoic pulses. The Cenozoic pulses are subdivided into a minor Eocene (44-39 Ma) and more prominent early Miocene to Pliocene (22-8 Ma) events. Intrusion of the batholith seems to have been strongly influenced by the presence of the Liquiñe-Ofqui Fault Zone, a long margin-parallel dextral strike-slip fault zone. Metamorphosed pillow basalts next to the fault zone are dated, within very large error, to sometime in the period 46-20 Ma, and demonstrate the formation of an oceanic basin (Hervé et al., 1995). These events have been interpreted in terms of the history of Farallon/Nazca-South America plate convergence as modeled by Pardo-Casas and Molnar (1987). Pankhurst et al. (1999) relate the pulsed magmatism to periods of rapid orthogonal convergence in that history. Hervé et al. (1995) relate the formation of an oceanic basin on the Liquiñe-Ofqui Fault Zone to complicated fault block motions set up during oblique phases of the same convergence.
Our rotations are calculated with the benefit of more detailed and reliable data sets in a shorter plate circuit than were available to PardoCasas and Molnar (1987), so that their resolution is likely to be better and their accumulated errors are likely to be smaller. We show calculated convergence data for both circuits in Fig. 10. The circuits produce comparable Farallon-South American plate convergence histories after chron 21 (45.4-47.2 Ma). Prior to this time, Pardo-Casas and Molnar's (1987) rotations predict that a period of very slow oblique divergence preceded the later convergence of the South American and Farallon plates. In contrast, our rotations imply that very slight or zero relative motion started to give way to convergence at chron 21 . The pre-chron 21 period is not accompanied by any evidence for subduction-related magmatism in Aysén (Pankhurst et al., 1999) and overlaps, within error, Hervé et al.'s (1995) estimate for the time of oceanic basin formation on the Liquiñe-Ofqui Fault Zone. Pardo-Casas and Molnar's (1987) construction of the circuit therefore suggests that the reason for this basin formation may be that the margin was accommodating early-tomid-Eocene plate divergence. Our circuit does not reproduce this suggestion, featuring instead slow or zero convergence that is merely consistent with the lack of a contemporary subduction record.

In both circuits, a rapid convergence phase begins around chron 21 with an increase in relative plate motion rate to more than $50 \mathrm{~km} /$ Myr. The newer circuit uses rotations that show how the convergence rate subsequently halves again at $39 \mathrm{Ma}$, whereas Pardo-Casas and Molnar's (1987) circuit lacks the resolution to show this. This short period ( 47-39 Ma) of relatively fast convergence coincides with Pankhurst et al.'s (1999) small Eocene magmatic pulse in the North Patagonian batholith. Events at Aysén at this time thus mirror those at the

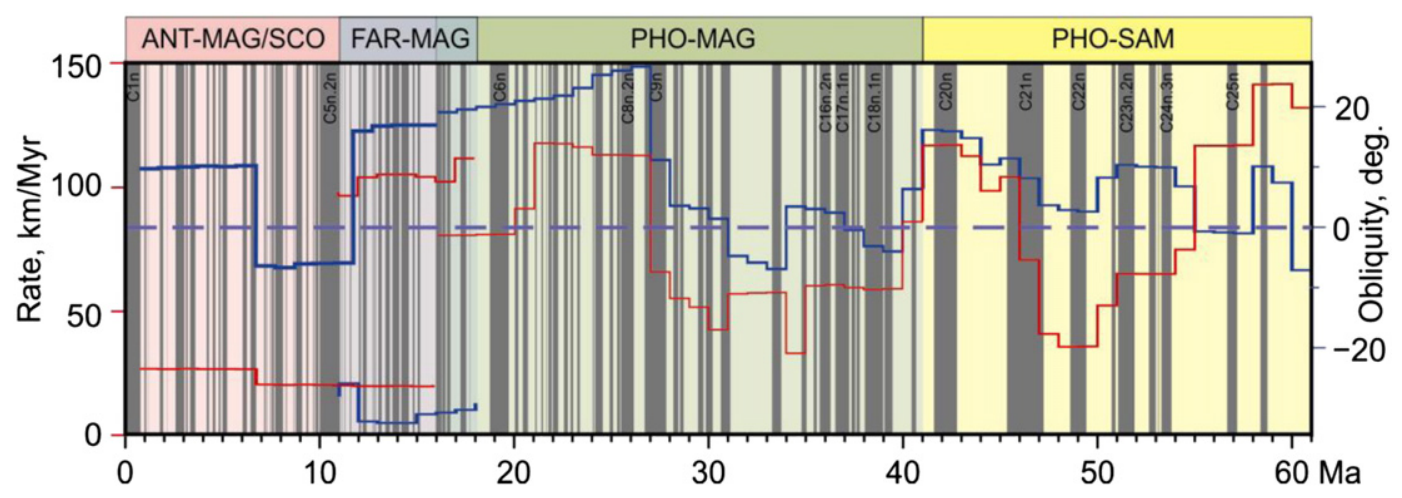

Fig. 11. Rates and obliquities to trench of convergence at $70^{\circ} \mathrm{W}, 56.8^{\circ} \mathrm{S}$ on the Fuegian margin since $61 \mathrm{Ma}$. Ornament as in Figs. 9 and 10. 
South Shetland Islands. Barbeau et al. (2009) and Zahid and Barbeau (2013) present evidence for an abrupt change at $39 \mathrm{Ma}$ in the provenance of zircons in sandstones and the Nd isotopic ratios of mudstones from the Magallanes Basin to the southeast, which suggest the magmatic pulse also accompanied uplift and exhumation of arc rocks in the southern Andes. A later increase in convergence rate (by $100 \mathrm{~km} / \mathrm{Myr}$ ) is much greater than that accompanying the Eocene magmatic pulse, but similar to the older events it is quickly followed by the onset of another pulse of calcalkaline magmatism (Pankhurst et al., 1999). The similarities between these three correlations invite a general interpretation of batholith growth during phases of melt production enhanced by increases in subduction rate that in turn are driven by increases in plate convergence rate.

The Fuegian margin lies between the Antarctic Peninsula and North Patagonian batholith. Tonalities and quartz diorites of the Seno Año Nuevo plutonic group were emplaced in southern Tierra del Fuego at 60-34 Ma (Hervé et al., 1984). Errors on the mixed Rb-Sr and $\mathrm{K}-\mathrm{Ar}$ ages from these bodies are large, and it is not possible to discern whether or not this activity may have pulsed as at Aysén and the South Shetland Islands. After a hiatus, calc-alkaline volcanism resumed briefly at Peninsula Hardy in earliest Miocene times before ceasing again until recently (Puig et al., 1984). The absence of calc-alkaline volcanism in this later period might be related to the approach of the FarallonPhoenix ridge off the margin's western end at $~ 30 \mathrm{Ma}$ (Fig. 8), and the subduction of young, volatile-poor, buoyant oceanic lithosphere. Southeast of the subducting ridge, Phoenix-South America/Magallanes plate motions were fast, but nearly parallel (usually $<20^{\circ}$ ) to this segment of the margin at all times since $61 \mathrm{Ma}$ (Fig. 11). The Seno Año and Peninsula Hardy magmatism may thus be less straightforwardly related to subduction than that to the north and south, perhaps reflecting interactions between the Phoenix-Magallanes transform margin and melt produced from deeper parts of the Phoenix plate being subducted underneath it from further north. Northwest of the ridge, Farallon/Nazca and, later, Antarctic motion with respect to the Fuegian margin was slow and convergent or obliquely convergent, and may therefore have a more conventional subduction relationship to the Miocene and later phase of volcanism.

In the interior of Tierra del Fuego, recent work has sharpened definition in the developmental chronology of the Fuegian Andes. Gombosi et al. (2009) related a period of intensified crustal cooling at 48-34 Ma to crustal thickening and uplift. As well as the abundant accompanying evidence for thrust faulting and folding (e.g. Klepeis et al, 2010) there are indications that the Fuegian Andes also experienced Paleogene extension (Dalziel and Brown, 1989; Ghiglione et al., 2008). While the onset of this period coincides with a period of faster oblique PhoenixSouth American motions at the Fuegian margin (Fig. 11), the obliquity implies a mixed history of slight $(\sim 15 \mathrm{~km})$ convergent and divergent motions orthogonal to the margin, which is difficult to reconcile with the intense event interpreted by Gombosi et al. (2009). It is more appropriate to relate the convergent history of the Fuegian Andes to relative plate motions on a precursor to the North Scotia Ridge-MagallanesFagnano plate boundary. Eagles and Jokat's (2014) regional plate motion model for Eocene times show this boundary accommodating larger (50-100 km) convergent and divergent motions that are broadly consistent with the mixed evidence from Paleogene rocks in Tierra del Fuego, albeit within the level of the modeling uncertainties (Eagles and Jokat, 2014).

\section{Conclusions}

Our new model for relative motions of the Phoenix and West Antarctic plates in the period 61-3.3 Ma shows that the Phoenix plate moved around rotation poles situated near its southwestern corner. For much of the period, the oceanic lithosphere subducting near this corner was considerably younger than that further north. This pattern suggests that slab buoyancy forces from the subducted parts of the Phoenix plate contributed considerably to the net driving torque on it.
By applying the rotations in a plate circuit, we generate a first detailed history of the motions of the now-subducted Farallon-Phoenix mid-ocean ridge in the southeast Pacific prior to $17 \mathrm{Ma}$. These motions are consistent with independent estimates of the ridge's location based on evidence for its collision with the South American plate, and also show those independent estimates to be mutually-consistent. The rotations for ridge and plate motion also enable us to calculate histories of convergence rates and directions, and their segmentation along the Chile Trench, at times before $17 \mathrm{Ma}$. Early Eocene times saw no relative motion between the Farallon and South American plates at Aysén, Chile, or possibly very slow divergent motion that may have led to the opening of a narrow oceanic basin. Convergent motion between the plates started at chron 21 (45-47 Ma). A pulse of subduction-related magmatic activity started around $44 \mathrm{Ma}$ following this convergence, and was mirrored on the Antarctic Peninsula where the Phoenix plate was also undergoing subduction. A later pulse, at 25-15 Ma at Aysén, can be related to a longer-lived and greater increase in Nazca plate convergence rate with the South American plate. Between these regions, relative plate motions were parallel to the Fuegian margin between $61 \mathrm{Ma}$ and $\sim 20 \mathrm{Ma}$. Around $20 \mathrm{Ma}$, the western end of this margin embarked on a succession of collisions with the Nazca-Phoenix ridge, the Nazca plate on its northern edge, the Chile Rise, and the Antarctic plate on its southern edge. Further east, the Phoenix plate continued to move parallel to the Fuegian margin until its incorporation into the Antarctic plate at $3.3 \mathrm{Ma}$, since when the margin has accommodated slow oblique plate convergence.

\section{Acknowledgments}

We thank the editors and reviewers for their attention to our work. B.G.C.S. acknowledges the Nuffield Foundation. G.E. thanks the organizers for the invitation to present at the Scotia Arc workshop, and Rex Pilger for pointing out a format error in an earlier version of one of the tables.

\section{References}

Barbeau Jr., D.L., Olivero, E.B.,Swanson-Hysell, N.L.,Zahid, K.M., Murray, K.E., Gehrels, G.E., 2009. Detrital-zircon geochronology of the eastern Magallanes foreland basin: implications for Eocene kinematics of the northern Scotia Arc and Drake Passage. Earth Planet. Sci. Lett. 284, 489-503. http://dx.doi.org/10.1016/j.epsl.2009.05.014.

Barker, P.F., 1982. The Cenozoic subduction history of the Pacific margin of the Antarctic Peninsula: Ridge crest-trench interactions. J. Geol. Soc. London 139, 787-801.

Breitsprecher, K., Thorkelsen, D.J., 2009. Neogene kinematic history of Nazca-AntarcticPhoenix slab windows beneath Patagonia and the Antarctic Peninsula. Tectonophysics 464, 10-20.

Brown, B., Gaina, C., Müller, R.D., 2006. Circum-Antarctic palaeobathymetry: illustrated examples from Cenozoic to recent times. Palaeogeogr. Palaeoclimatol. Palaeoecol. 231, 158-168. http://dx.doi.org/10.1016/j.palaeo.2005.07.033.

Cande, S.C., Kent, D.V., 1995. Revised calibration of the geomagnetic polarity timescale for the Late Cretaceous and Cenozoic. J. Geophys. Res. 100, 6093-6095. http://dx.doi.org/ 10.1029/94JB03098.

Cande, S.C., Leslie, R.B., 1986. Late Cenozoic tectonics of the Southern Chile trench. J. Geophys. Res. 91, 471-496. http://dx.doi.org/10.1029/JB091iB01p00471.

Cande, S.C., Stock, J.M., 2004. Cenozoic reconstructions of the Australia-New ZealandSouth Pacific sector of Antarctica. In: Exon, N.F., Kennett, J.P., Malone, M.J. (Eds.), The Cenozoic Southern Ocean: tectonics, sedimentation, and climate change between Australia and Antarctica. American Geophysical Union, Washington, DC, pp. 5-18.

Cande, S.C., Raymond, C.A.,Stock, J., Haxby, W.F., 1995. Geophysics of the Pitman Fracture Zone and Pacific-Antarctic plate motions during the Cenozoic. Science 270, 947-953. http://dx.doi.org/10.1126/science.270.5238.947.

Cande, S.C.,Stock, J.M., Muller, R.D., Ishihara, T., 2000. Cenozoic motion between East and West Antarctica. Nature 404, 145-150.

Dalziel, I.W.D., Brown, R.L., 1989. Tectonic denudation of the Darwin metamorphic core complex in the Andes of Tierra del Fuego, southernmost Chile: implications for Cordilleran orogenesis. Geology 17, 699-703.

D'Orazio, M.,Agostini, S.,Mazzarini, F.,Innocenti, F.,Manetti, P., Haller, M.J.,Lahsen, A., 2000. The Pali Aike volcanic field, Patagonia: slab- window magmatism near the southern tip of South America. Tectonophysics 321, 407-427.

D'Orazio, M., Agostini, S., Innocenti, F., Haller, M.J., Manetti, P., Mazzarini, F., 2001. Slab window-related magmatism from southernmost South America: the late Miocene mafic volcanics from the Estancia Glencross area $\left(\sim 52^{\circ} \mathrm{S}\right.$, Argentina-Chile). Lithos $57,67-89$.

D'Orazio, M., Innocenti, F., Manetti, P., Haller, M.J., 2004. Cenozoic back-arc magmatism of the southern extra-Andean Patagonia $\left(44^{\circ} 30^{\prime} \mathrm{S}-52^{\circ} \mathrm{S}\right)$ : a review of geochemical data and geodynamic interpretations. Rev. Asoc. Geol. Argent. 59, 525-538. 
Eagles, G., 2004. Tectonic evolution of the Antarctic-Phoenix plate system since $15 \mathrm{Ma}$. Earth Planet. Sci. Lett. 217, 97-109. http://dx.doi.org/10.1016/S0012-821X(03) 00584-3.

Eagles, G.,Jokat, W., 2014. Tectonic reconstructions for paleobathymetry in Drake Passage. Tectonophysics 611, 28-50. http://dx.doi.org/10.1016/j.tecto.2013.11.021.

Eagles, G., Gohl, K., Larter, R.D., 2004a. Life of the Bellingshausen plate. Geophys. Res. Lett. 31, L07603. http://dx.doi.org/10.1029/2003GL019127.

Eagles, G..Gohl, K.,Larter, R.D., 2004b. High-resolution animated tectonic reconstruction of the South Pacific and West Antarctic Margin. Geochem. Geophys. Geosyst. 5, Q07002. http://dx.doi.org/10.1029/2003GC000657.

Eagles, G., Livermore, R.A., Fairhead, J.D., Morris, P., 2005. Tectonic evolution of the west Scotia Sea. J. Geophys. Res. 110, B02401.

Eagles, G., Gohl, K., Larter, R.D., 2009a. Animated tectonic reconstruction of the Southern Pacific and alkaline volcanism at its convergent margins since Eocene times. Tectonophysics 464, 21-29. http://dx.doi.org/10.1016/j.tecto.2007.10.005.

Eagles, G., Larter, R.D., Gohl, K.,Vaughan, A.P.M., 2009b. West Antarctic Rift System in the Antarctic Peninsula. Geophys. Res. Lett. 36, L21305. http://dx.doi.org/10.1029/ 2009 GL040721.

Espinoza, F., Morata, D.,Pelleter, E., Maury, R.C.,Suárez, M.,Lagabrielle, Y.,Polvé, M., Bellon, H., Cotten, J., De la Cruz, R., Guivel, C., 2005. Petrogenesis of the Eocene and Mio-Pliocene alkaline basaltic magmatism in Meseta Chile Chico, southern Patagonia, Chile: evidence for the participation of two slab windows. Lithos 82, 315-343. http://dx.doi.org/10. 1016/j.lithos.2004.09.024.

Fosdick, J.C., Grove, M., Hourigan, J.K., Calderón, M., 2013. Retroarc deformation and exhumation near the end of the Andes, southern Patagonia. Earth Planet. Sci. Lett. 361, 504-517. http://dx.doi.org/10.1016/j.epsl.2012.12.007.

Ghiglione, M.C., Yagupsky, D., Ghidella, M., Ramos, V.A., 2008. Continental stretching preceded the opening of the Drake Passage: evidence from Tierra del Fuego. Geology 36, 643-646. http://dx.doi.org/10.1130/G24857A.1.

Gombosi, D.J., Barbeau Jr., D.L., Garver, J.I., 2009. New thermochronometric constraints on the rapid Palaeogene exhumation of the Cordillera Darwin complex and related thrust sheets in the Fuegian Andes. Terra Nova 21, 507-515. http://dx.doi.org/10. 1111/j.1365-3121.2009.00908.x.

Gorring, M.L., Kay, S.M., Zeitler, P.K., Ramos, V.A., Rubiolo, D., Fernandez, M.I., Panza, J.L., 1997. Neogene Patagonian plateau lavas: continental magmas associated with ridge collision at the Chile Triple Junction. Tectonics 16, 1-17.

Gradstein, F.M., et al., 2004. A Geologic Time Scale 2004. Cambridge University Press, Cambridge, (589 pp).

Hervé, M.,Suárez, M.,Puig, A., 1984. The Patagonian batholith S of Tierra del Fuego, Chile: timing and tectonic implications. J. Geol. Soc. Lond. 141, 909-917.

Hervé, F., Pankhurst, R.J., Drake, R., Beck, M.E., 1995. Pillow metabasalts in a mid-Tertiary extensional basin adjacent to the Liquiñe-Ofqui fault zone: the Isla Magdalena area, Aysén, Chile. J. S. Am. Earth Sci. 8, 33-46.

Hole, M., Larter, R.D., 1993. Trench-proximal volcanism following ridge-crest-trench collision along the Antarctic Peninsula. Tectonics 12, 897-910.

Huang, F., Lundstrom, C.C., 2007. ${ }^{231}$ Pa excesses in arc volcanic rocks: constraint on melting rates and convergent margins. Geology 35, 1007-1010.

Klepeis, K., Betka, P., Clarke, G., Fanning, M., Hervé, F., Rojas, L., Mpodozis, C., Thomson, S., 2010. Continental underthrusting and obduction during the Cretaceous closure of the Rocas Verdes rift basin, Cordillera Darwin, Patagonian Andes. Tectonics 29, TC3014. http://dx.doi.org/10.1029/2009TC002610.

Larter, R.D., Barker, P.F., 1991. Effects of ridge-crest trench interaction on Antarctic-Phoenix spreading: forces on a young subducting plate. J. Geophys. Res. 96, 19583-19607.

Livermore, R.A., et al., 2000. Autopsy on a dead spreading center: the Phoenix Ridge, Drake Passage, Antarctica. Geology 28, 607-610.

Livermore, R.A., Eagles, G., Morris, P., Maldonado, A., 2004. Shackleton fracture zone: no barrier to early circumpolar ocean circulation. Geology 32, 797-800.

Livermore, R.A., Nankivell, A.P., Eagles, G., Morris, P., 2005. Paleogene opening of Drake Passage. Earth Planet. Sci. Lett. 236, 459-470.
Maloney, K.T.,Clarke, G.L.,Klepeis, K.A.,Quevedo, L., 2013. The Late Jurassic to present evolution of the Andean margin: drivers and the geological record. Tectonics 32 (5), 1049-1065. http://dx.doi.org/10.1002/tect.20067.

McCarron, J.J.,Larter, R.D., 1998. Late Cretaceous to early Tertiary subduction history of the Antarctic Peninsula. J. Geol. Soc. 155, 255-268. http://dx.doi.org/10.1144/gsjgs.155.2. 0255.

Meschede, M., Barckhausen, U., 2000. The plate tectonic evolution of the Cocos-Nazca spreading center, Proc. ODP, Scientific Results. http://www-odp.tamu.edu/ publications/170_SR/170TOC.HTM.

Nankivell, A.P., 1997. Tectonic evolution of the Southern Ocean between Antarctica, South America and Africa over the last $84 \mathrm{Ma}$. (Ph.D. thesis) Univ. of Oxford, Oxford, UK.

Pankhurst, R.J.,Weaver, S.D.,Hervé, F., Larrondo, P., 1999. Mesozoic-Cenozoic evolution of the North Patagonian Batholith in Aysen, southern Chile. J. Geol. Soc. Lond. 156, 673-694. http://dx.doi.org/10.1144/gsjgs.156.4.0673.

Pardo-Casas, F., Molnar, P., 1987. Relative motion of the Nazca (Farallon) and South American Plates since Late Cretaceous time. Tectonics 6, 233-248. http://dx.doi.org 10.1029/TC006i003p00233.

Puig, A.,Herve, M.,Suarez, M.,Saunders, A.D., 1984. Calc-alkaline and alkaline Miocene and calc-alkaline recent volcanism in the southernmost Patagonian cordillera, Chile. J. Volcanol. Geotherm. Res. 21, 149-163.

Ramos, V.A., Kay, S.M., 1992. Southern Patagonian plateau basalts and deformation: backarc testimony of ridge collisions. Tectonophysics 205, 261-282.

Rex, D.C., 1976. Geochronology in relation to the stratigraphy of the Antarctic Peninsula. Br. Antarct. Surv. Bull. 43, 49-58.

Roterman, C.N., Copley, J.T., Linse, K.T., Tyler, P.A., Rogers, A.D., 2013. The biogeography of the yeti crabs (Kiwaidae) with notes on the phylogeny of the Chirostyloidea (Decapoda: Anomura). Proc. R. Soc. B 280, 20130718. http://dx.doi.org/10.1098/ rspb.2013.0718.

Rowan, C.J., Rowley, D.B., 2014. Spreading behaviour of the Pacific-Farallon ridge system since 83 Ma. Geophys. J. Int. http://dx.doi.org/10.1093/gji/ggu056 (published online).

Sandwell, D.T.,Smith, W.H.F., 2009. Global marine gravity from retracked Geosat and ERS1 altimetry: ridge segmentation versus spreading rate. J. Geophys. Res. 114, B01411.

Sdrolias, M., Müller, R.D., 2006. Controls on Back-arc basin formation. Geochem. Geophys. Geosyst. 7, Q04016. http://dx.doi.org/10.1029/2005GC001090.

Seton, M.,Müller, R.D.,Zahirovic, S., Gaina, C.,Torsvik, T.,Shephard, G.,Talsma, A.,Gurnis, M., Turner, M., Maus, S., Chandler, M., 2012. Global continental and ocean basin reconstructions since 200 Ma. Earth-Sci. Rev. 113, 212-270. http://dx.doi.org/10.1016/j earscirev.2012.03.002.

Smalley, R., Dalziel, I.W.D., Bevis, M.G., Kendrick, E., Stamps, D.S., et al., 2007. Scotia arc kinematics from GPS geodesy. Geophys. Res. Lett. 34, L21308.

Somoza, R.,Ghidella, M.E., 2012. Late Cretaceous to recent plate motions in western South America revisited. Earth Planet. Sci. Lett. 331-332, 152-163. http://dx.doi.org/10. 1016/j.epsl.2012.03.003.

Stern, C.R., 2004. Active Andean volcanism: its geologic and tectonic setting. Rev. Geol. Chile 31, 161-206. http://dx.doi.org/10.4067/S0716-02082004000200001.

Suárez, M., de la Cruz, R., Bell, C.M., 2000. Timing and origin of deformation along the Patagonian fold and thrust belt. Geol. Mag. 137, 345-353.

Wang, F., Zheng, X.-S., Lee, J.I.K., Choe, W.H., Evans, N., Zhu, R.-X., 2009. An ${ }^{40} \mathrm{Ar} /{ }^{39} \mathrm{Ar}$ geochronology on a mid-Eocene igneous event on the Barton and Weaver peninsulas: implications for the dynamic setting of the Antarctic Peninsula. Geochem. Geophys. Geosyst. 10, Q12006. http://dx.doi.org/10.1029/2009GC002874.

Zahid, K.M., Barbeau Jr., D.L., 2013. Geochemical signatures from the Atlantic coast of Tierra del Fuego and their provenance implications for Magallanes basin sediments. Chem. Geol. 347, 69-81. http://dx.doi.org/10.1016/j.chemgeo.2013.03.004. 